\title{
ACCESSIBILITY AND ATTRACTIVENESS OF PRIMARY CARE SERVICES IN ALGERIA: MODELS OF SPATIAL INTERACTION OF THE NHPF OF THE EASTERN HEALTH REGION
} Nasreddine AISSAOUI ${ }^{\star}$, Said BRIKA ${ }^{\star} \star$

\begin{abstract}
The restructuring of basic health care structures represented by public institutions nearby care in Algeria, according to Executive Decree 07/140 of 19 May 2007, could have effects both positive and negative: positive effects as we quote the approximation of diversified health services towards the citizen. As for the negative effects they live in ignorance of the real role of this kind of structure, namely the prevention in the broad sense of the term before the one of care.

Among the results of our case study on the 7 wilayas of eastern Algeria, we noted: a small financial allocation and a shortage of medical and paramedical human resources, which have frozen the role of these NHPF, and which have favored the caregiver's recourse to hospital emergencies. On the other hand, we have also noticed the sufficient number of these structures throughout all the communes of the country and their proximity to the living environments, despite the derisory number of services rendered, which were able to meet certain needs of the inhabitants.
\end{abstract}

Keyword: Primary care services, access to basic health care, nearby health care facilities, public health in Algeria

JEL Code: Q14, Q15, Q18

Citation: AISSAOUI, N., BRIKA, S. (2017). Accessibility and attractiveness of primary care services in Algeria: Models of spatial interaction of the NHPF of the Eastern Health Region. Journal of Finance and Corporate Governance, Vol., 1, No. 2: pp. 24 - 34. (Dec 2017); ISSN: 2602-5655.

\footnotetext{
$\star$ aissaoui.n2012@gmail.com, Oum El Bouaghi University, Algeria.

$\star \star$ saidbrika@yahoo.fr, Oum El Bouaghi University, Algeria.
} 


\section{INTRODUCTION}

The eighties and nineties were marked by lively discussions on health security and the challenge of new epidemics, in particular the emergence of heavy transmissible and noncommunicable diseases (HIV, Cancer, etc.). Despite the efforts made at national or international level, much remains to be done concerning scientific research, prevention, and protection against these pathologies.

Today, it is mainly the issues of proximity to care that motivate citizens' concerns (Gabrielli, 2001: 17-18). For many, it has become more convenient to go directly to hospital emergencies than to find a doctor who can take care of their health needs near their home (Aissaoui \& Brahamia, 2014: 65-79).

Finally, to be complete, the expected solutions of new information and communication technologies are slow to unfold, while they make it easier than yesterday to coordinate care and ensure its relevance. For this, we will address in this paper a theoretical and organizational approach to local care, the different conditions that boost this kind of health service.

We will try through this paper to answer the following question: what role can be played by primary care in the supply of care in Algeria? And what are the conditions that can improve accessibility to NHPF?

\section{MATERIELS \& METHODS}

\subsection{Identification of the study area and its components}

We conducted a study during the year 2012 which grouped 7 wilayas of Eastern Algeria on 14 NHPF ; 2 NHPF in each wilaya, one of them located in the chief town of the wilaya:

The 7 considered wilayas of eastern Algeria are:

- Oum El Bouaghi ;

- Batna ;

- Tébessa ;

- Skikda ;

- Constantine ;

- Khenchla ;

- Souk Ahras.

The wilayas selected in the survey have the characteristics presented in table 1 . 
Vol. 1, No. 2 (Dec 2017); ISSN: 2602-5655

Table 1: Characteristics of the wilayas concerned by the survey

\begin{tabular}{|c|c|c|c|c|c|c|c|}
\hline & $\begin{array}{c}\text { Oum } \\
\text { El } \\
\text { Bouaghi }\end{array}$ & Batna & Tébessa & Skikda & Constantine & Khenchla & Souk Ahras \\
\hline Geographic location & inside & inside & border & coastal & inside & inside & border \\
\hline $\begin{array}{l}\text { Number of } \\
\text { inhabitants }\end{array}$ & 736992 & 1265120 & 730306 & 1019000 & 1082460 & 449220 & 496400 \\
\hline $\begin{array}{l}\text { Number of } \\
\text { municipalities }\end{array}$ & 29 & 61 & 28 & 38 & 12 & 21 & 26 \\
\hline Number of NHPF $\mathrm{s} *$ & 147 & 330 & 168 & 223 & 108 & 118 & 93 \\
\hline NUMBER OF UHC ** & - & 1 & - & - & 1 & - & - \\
\hline
\end{tabular}

Source : Santé en Chiffres 2015, MSPRH, direction des études et de la planification, Edition juillet 2016

(*) : NeARby Health PUblic FaCilities / NHPF ; (**) : University HosPital Centers /UHC

\subsection{Selected indicators}

We distributed 515 questionnaires, and we recovered 472, so the recovery rate is around $92 \%$. The survey questionnaire is organized in 7 axes and contains 45 questions. Among the axes of this questionnaire: the seventh axis which gathers some determinants of accessibility (geographical, financial and organizational). Having an idea about the care-seeker's answers, can inform us about the basis of care-seekers' choices to choose one institution and not to choose others.

The indicators chosen to gauge the accessibility and attractiveness of NHPF are:

- Degrees of distance from home care infrastructure of the care recipient;

- Degrees of influence of financial capacity on the demand for care;

- Degrees of influence of prejudices on the quality of material means;

- Degrees of influence of prejudice on the quality of human resources;

- Degrees of influence of waiting time on the demand for care;

- The quality of reception reserved to the care seeker;

- The claimant's perception of equity;

- The quality of services according to the care recipient;

- The quality of the human relationships with the treating physician according to the care recipient;

- Respect of the hours of services;

- The assurance of permanence in the nights and weekends.

\subsection{Statistical methods}

The statistical results are obtained through a Statistical Package for the Social Sciences / SPSS.16 software. Among the statistical tools used to test hypotheses is Analysis of variance / ANOVA.

\subsection{Sample composition and statistical tests of the survey}

\subsubsection{Composition of the sample}

In order for our sample to be descriptive, we have chosen the number of questionnaires to be distributed, in relation to the $1 / 10000$ ratio of the resident population in each wilaya of the 7 wilayas of the survey. 


\subsubsection{Cronbach's alpha coefficient}

Cronbach's alpha coefficient, sometimes called simply coefficient, is a statistic used to measure the internal consistency (or reliability) of the questions asked during a test, and its value is between [0.1]. The coefficient value for this survey is 0.683 , being considered "acceptable" from 0.6.

\subsubsection{Kolmogorov-Smirnov test}

In statistics, the Kolmogorov-Smirnov or K-S test is a hypothesis test used to determine whether a sample follows a given law known by its continuous distribution function, or whether two samples follow the same law. The use of this K-S test allowed us to have an idea about the nature of the observed distribution of the variables of this sample. Through SPSS, it is thus decided that our sample comes from normal law.

\section{RESULTS \& DISCUSSION}

\subsection{Results}

We tried through this survey; to highlight the accessibility variables for either general care or specialized care, which can be provided by the public facilities of local care / NHPF in the eastern health region of Algeria.

\subsubsection{Specificity of accessibility to general care of NHPF}

Table 2: Analysis of Variants of Accessibility to General Care of NHPF (ANOVA)

\begin{tabular}{|c|c|c|c|c|c|c|}
\hline & & $\begin{array}{l}\text { Sum of } \\
\text { Squares }\end{array}$ & df & $\begin{array}{l}\text { Mean } \\
\text { Square }\end{array}$ & $\mathrm{F}$ & Sig. \\
\hline \multirow{3}{*}{$\begin{array}{l}\text { Degrees of removal from } \\
\text { home care infrastructure } \\
\text { of the care recipient }\end{array}$} & Between Groups & 5,195 & 2 & 2,597 & \multirow[t]{3}{*}{3,260} & \multirow[t]{3}{*}{,039 } \\
\hline & Within Groups & 373,684 & 469 & ,797 & & \\
\hline & Total & 378,879 & 471 & & & \\
\hline \multirow{3}{*}{$\begin{array}{l}\text { Degrees of influence of } \\
\text { financial capacity on the } \\
\text { demand for care }\end{array}$} & Between Groups &, 581 & 2 & ,290 & \multirow[t]{3}{*}{, 830} & \multirow[t]{3}{*}{,437 } \\
\hline & Within Groups & 164,112 & 469 &, 350 & & \\
\hline & Total & 164,693 & 471 & & & \\
\hline \multirow{3}{*}{$\begin{array}{l}\text { Degrees of influence of } \\
\text { prejudice on the quality } \\
\text { of material means within } \\
\text { the NHPF }\end{array}$} & Between Groups & ,911 & 2 &, 455 & \multirow[t]{3}{*}{1,640} & \multirow[t]{3}{*}{,195 } \\
\hline & Within Groups & 130,206 & 469 &, 278 & & \\
\hline & Total & 131,117 & 471 & & & \\
\hline \multirow{3}{*}{$\begin{array}{l}\text { Degrees of Influence of } \\
\text { Prejudice on the Quality } \\
\text { of Human Resources }\end{array}$} & Between Groups & 1,210 & 2 & 605 & \multirow[t]{3}{*}{1,921} & \multirow[t]{3}{*}{,148 } \\
\hline & Within Groups & 147,731 & 469 &, 315 & & \\
\hline & Total & 148,941 & 471 & & & \\
\hline Degrees of influence of & Between Groups & 2,071 & 2 & 1,036 & 2,263 &, 105 \\
\hline
\end{tabular}


Vol. 1, No. 2 (Dec 2017); ISSN: 2602-5655

waiting time on the demand for care

$\begin{array}{llll}\text { Within Groups } & 214,632 & 469 & , 458 \\ \text { Total } & 216,703 & 471\end{array}$

The quality of reception reserved to the care seeker

Between Groups

1,246

2

, 623

1,227

, 294

Within Groups $\quad$ 238,245 $\quad 469$

Total $\quad 239,492 \quad 471$

The perception of equity by the care recipient

Between Groups

, 434

2

, 217

, 868

, 421

Within Groups

117,261

469

, 250

Total

117,695

471

Quality of services according to the care requestor

Between Groups

$2,042 \quad 2$

2

1,021

3,593

,028

Within Groups

$133,272 \quad 469$

,284

Total

135,314

471

The quality of human relations with the treating physician according to the care requestor

Between Groups

5,219

2

2,610

4,952

, 007

Within Groups

247,154

469

, 527

Total

252,373

471

The respect of the schedules of services

Between Groups

1,176

2

, 588

2,979

, 052

Within Groups

92,568

469

, 197

Total

93,744

471

Overnight insurance on nights and weekends

Between Groups

, 738

2

,369

1,209

,300

$\begin{array}{llll}\text { Within Groups } & 143,219 & 469 & , 305 \\ \text { Total } & 143,958 & 471\end{array}$

Source: made by us

We can see that there is an interrelation between the accessibility to general care and the geographic factor (distance), which, according to the majority of health care seekers, contributes to their decisions, even though each municipality has a NHPF at minimum. This truth is shared by several international studies but to different degrees. In addition to the geographical factor, we found that prejudices and experiences on the quality of care provided by the NHPF on the one hand, in the other hand, the quality of reception that is reserved for organizational factors) significantly affect the patient's decision to choose the facility. 


\subsubsection{Specificity of accessibility to specialized care of PSE}

Table 3: Analysis of Variants of Specialized Accessibility of NHPF (ANOVA)

\begin{tabular}{|c|c|c|c|c|c|c|}
\hline & & $\begin{array}{l}\text { Sum of } \\
\text { Squares }\end{array}$ & df & Mean Square & $\mathbf{F}$ & Sig. \\
\hline \multirow{3}{*}{$\begin{array}{l}\text { Degrees of removal from } \\
\text { home care infrastructure of } \\
\text { the care recipient }\end{array}$} & Between Groups & 7,362 & 2 & 3,681 & 4,647 &, 010 \\
\hline & Within Groups & 371,518 & 469 & ,792 & & \\
\hline & Total & 378,879 & 471 & & & \\
\hline \multirow{3}{*}{$\begin{array}{l}\text { Degrees of influence of } \\
\text { financial capacity on the } \\
\text { demand for care }\end{array}$} & Between Groups & ,485 & 2 &, 242 & ,692 &, 501 \\
\hline & Within Groups & 164,208 & 469 & ,350 & & \\
\hline & Total & 164,693 & 471 & & & \\
\hline \multirow{3}{*}{$\begin{array}{l}\text { Degrees of influence of } \\
\text { prejudice on the quality of } \\
\text { material means within the } \\
\text { NHPF }\end{array}$} & Between Groups & ,246 & 2 &, 123 &, 442 & ,643 \\
\hline & Within Groups & 130,870 & 469 & ,279 & & \\
\hline & Total & 131,117 & 471 & & & \\
\hline \multirow{3}{*}{$\begin{array}{l}\text { Degrees of Influence of } \\
\text { Prejudice on the Quality of } \\
\text { Human Resources }\end{array}$} & Between Groups & 1,762 & 2 &, 881 & 2,807 &, 061 \\
\hline & Within Groups & 147,179 & 469 & ,314 & & \\
\hline & Total & 148,941 & 471 & & & \\
\hline \multirow{3}{*}{$\begin{array}{l}\text { Degrees of influence of } \\
\text { waiting time on the demand } \\
\text { for care }\end{array}$} & Between Groups & 2,939 & 2 & 1,469 & 3,224 &, 041 \\
\hline & Within Groups & 213,765 & 469 & ,456 & & \\
\hline & Total & 216,703 & 471 & & & \\
\hline \multirow{3}{*}{$\begin{array}{l}\text { The quality of reception } \\
\text { reserved to the care seeker }\end{array}$} & Between Groups & 1,233 & 2 & 617 & 1,214 & ,298 \\
\hline & Within Groups & 238,258 & 469 &, 508 & & \\
\hline & Total & 239,492 & 471 & & & \\
\hline \multirow{3}{*}{$\begin{array}{l}\text { The perception of equity by } \\
\text { the care recipient }\end{array}$} & Between Groups & 1,230 & 2 & ,615 & 2,477 &, 085 \\
\hline & Within Groups & 116,465 & 469 & ,248 & & \\
\hline & Total & 117,695 & 471 & & & \\
\hline \multirow{3}{*}{$\begin{array}{l}\text { Quality of services according } \\
\text { to the care requestor }\end{array}$} & Between Groups &, 737 & 2 & ,369 & 1,285 & 278 \\
\hline & Within Groups & 134,576 & 469 & ,287 & & \\
\hline & Total & 135,314 & 471 & & & \\
\hline \multirow{3}{*}{$\begin{array}{l}\text { The quality of human } \\
\text { relations with the treating } \\
\text { physician according to the } \\
\text { care requestor }\end{array}$} & Between Groups & 2,040 & 2 & 1,020 & 1,911 & 149 \\
\hline & Within Groups & 250,333 & 469 &, 534 & & \\
\hline & Total & 252,373 & 471 & & & \\
\hline
\end{tabular}


Vol. 1, No. 2 (Dec 2017); ISSN: 2602-5655

\begin{tabular}{|c|c|c|c|c|c|c|}
\hline \multirow{3}{*}{$\begin{array}{l}\text { The respect of the schedules } \\
\text { of services }\end{array}$} & Between Groups & ,941 & 2 & ,471 & 2,378 &, 094 \\
\hline & Within Groups & 92,803 & 469 & 198 & & \\
\hline & Total & 93,744 & 471 & & & \\
\hline \multirow{3}{*}{$\begin{array}{l}\text { Overnight insurance on } \\
\text { nights and weekends }\end{array}$} & Between Groups & 1,345 & 2 & ,672 & 2,211 & 111 \\
\hline & Within Groups & 142,613 & 469 & ,304 & & \\
\hline & Total & 143,958 & 471 & & & \\
\hline
\end{tabular}

Source: made by us

What is noted for general care is valid for specialized care, the geographical factor (distance) greatly influences the decision of the care recipient. This truth is also shared by several international studies but to different degrees. In addition to the geographic factor, we found that the length of time to have specialized care affects the care recipient's decision.

Unlike the majority of studies on this subject, the financial factor (affordability) has little influence on the decision of the patient, this is due again to the amount paid, which is derisory compared to the purchasing power of the majority of of households (Aissaoui \& Brahamia, 2014: 65-79).

\subsection{Discussion}

\subsubsection{Theoretical and organizational framework of primary care}

This section will highlight the Alma-Ata Declaration of 1978, which stipulates a greater role to be given to primary care in the different health systems, to better address the real health needs of community residents (www.desktop.arcgis.com).

\subsubsection{A theoretical and organizational approach to primary care in Algeria}

Primary care is the first line of defense against the disease, which justifies the growing importance, to varying degrees, of the health system for this type of health service, since Alma Ata in 1978. The importance of this type of care lies in their role, which consists in guaranteeing prevention services and basic health care in a close environment for the citizen, and also in meeting the high health needs of the population. Indeed, contributes to the establishment of the principles of progressive care, leaving hospitals to focus on care that requires lengthy treatment or specialized care (Hubert, 2010: 6).

Primary care is a fundamental part of any health care system. The failure to provide timely and adequate primary and preventative access to care, results in serious adverse events/SAEs, or unnecessary medical conditions, that may lead to avoidable hospitalization or avoidable prolongation of these states in time. These situations can affect the quality of life of those persons, and may have a negative impact on their productivity (Aissaoui, 2014: 105124).

Despite the diversity of primary care distributions, the overall goal remains the same for the different health systems. Nevertheless, the success of this type of health service must be based on two essential bases: equity in the distribution of primary care and its medical effectiveness. From an economic point of view, health expenditure can only be rationalized by taking into account the essential role and mission for which these structures were created, in this case prevention in the broad sense. 
Accessibility to care can be seen as a right for every individual. This right is not recent, it is mentioned in several international charters, such as the Ottawa Charter (1986), which emphasizes the equity in the distribution of care for all individuals by overcoming racial, social differences etc. This right was mentioned again in the Bangkok Charter a few years later (Aissaoui, 2017: 27-36).

We cannot deny the presence of contradictions in the same health system, such as inequality in the use of care on the one hand, and on the other hand, inequalities between the developed countries themselves (Bentham, 1995: 131-135). These inequalities become more and more important when we go from North to South. There are objective causes (chronic diseases ...) and other subjective (diet, dependence ...) that explain these inequalities, and which affect the individual's use of care (Frenk, 1985: 438).

\subsubsection{The model of gravity (from Newton ... to Ravenstein)}

\subsubsection{The laws of Ravenstein}

The number of migrants decreases as distance increases; most do not go very far; those who travel long distances, preferentially travel to large commercial and industrial centers (Ravenstein, 1985: 241-305).

The process is as follows: a fast-growing city attracts people from surrounding areas; the gaps thus created are filled by migrants from more distant districts; the force of attraction of the big dynamic cities is thus felt gradually by decreasing in intensity. The number of migrants in the reception area is therefore proportional to the population of the area of origin and inversely proportional to the distance between them (Noin, 1988: 273-274).

- Each main stream of migration creates countervailing current;

- Urban dwellers have lower mobility than rural people;

- Women have greater mobility than men, at least at short distances;

- The intensity of migration increases with the development of trade, industry and transport;

- The factors determining migration are numerous, but the most important is the economic factor.

\subsubsection{Spatial interaction and social relation}

A very common definition in the Anglo-Saxon literature, reduces the notion of spatial interaction to the phenomenon of decreasing flux with distance. The observation of migration at the end of the nineteenth century, led very early to different authors to highlight empirical laws (Ravenstein), which were then approximated by analogy of the laws of universal gravitation (www.desktop.arcgis.com).

The expression of relations between places, which underlie all the proposed definitions of spatial interaction, is undoubtedly a central stumbling block, which largely explains the hostile reactions that have been and still spatial interaction models. If this notion of relation between places does not give rise to particular difficulties in physical geography, where it can refer to concrete phenomena such as the displacement of air masses, or the transfer of a solid charge by watercourses, it is not the same in human geography, when one claims to describe social phenomena with the help of global laws of human behavior.

In human geography, relations between places, whether they are cities, regions or states, are in fact related to localized social or economic aggregates, most often 
heterogeneous, composed of individuals (individuals, households, companies, etc.) do not have the same income, the same mobility capabilities, the same information on remote relationship opportunities.

Spatial interaction models then postulate, most often implicitly, a double hypothesis of the relevance of the social and economic aggregates constituted, and the existence of an average behavior, that summarizes that of the individuals that make up these aggregates. Rather than considering phenomena of spatial interaction as an exogenous component of social behavior, it seems more interesting to consider that they constitute a global result. The most relevant justifications for spatial interaction models, are precisely those that demystify the effect of distance, and relate its influence to economic (Reilly), sociological (Stouffer) or cognitive (Hägerstrand) processes (www.grasland.script.univ-paris-diderot.fr).

\subsubsection{Accessibility and attractiveness of basic health care facilities in Algeria}

Among the results of our case study on the health region of eastern Algeria:

We note inequalities in health needs, we note also, inequalities in the means allocated to cover these needs in the communes of the same wilaya, and between the wilayas themselves. We found that the two wilayas of Constantine and Batna, which have a university hospital, have material and human resources superior than other wilayas, and among other things, health indices better than those of other wilayas. It may be thought that this is the result of good coordination between UHC and NHPF in the same wilaya (Aissaoui, $2017: 27-36$ ).

We have seen inequalities in the use of care provided by these facilities in the same wilaya, on the one hand, and on the other hand, between the wilayas itself. These inequalities are gaining momentum by going to the wilayas of the highlands, and the wilayas bordering Tunisia. Among the main causes of these inequalities: a low quality of care, a low financial endowment, a flagrant lack of specialists... these results call into question the health map and the distribution of primary care.

It has also been observed that wilayas with UHC have better health indices than other wilayas. This shows the close and complementary relationship between primary care and specialized care.

The results obtained showed that weak local economic development, especially in the wilayas of the highlands and wilayas bordering Tunisia, led to high rates of unemployment and consequently low purchasing power, high rates of unemployment. illiteracy, weak social relations, etc. which may have a negative impact on the daily life of the inhabitants, also affect their health in these wilayas.

Other results have shown that the determinants of accessibility to general care are not the same as for specialized care. These determinants are essentially: the distance traveled by the care seeker, the prejudices about the quality of care, some subjective illusions, etc. On the other hand, the financial means of the individual have little influence on the decision to care, the latter result does not agree with the majority of studies carried out in other health systems.

The sufficient number of general practitioners in the majority of basic health care facilities, during working hours and on-call duty, has absorbed a significant demand for care in this type of service.

The large number of serious adverse events of the NHPF, is synonymous with low quality of some services provided by these institutions. This gives us a clear idea 
about the work to be done in the short and medium term, to put a strategy that assesses, controls and corrects the causes of the low quality of these services... (Aissaoui, 2014: 105-124)

There was a negative bias among NHPF patients, regarding to the quality of the material and human resources of these facilities. This bias is most often mentioned, which influences the care provider's decision to not respect the graduation of care.

There are two possible explanations for the health needs not covered by the NHPF: the first concerns a bias on the availability of some care not provided by these institutions; the second is the caregiver's habit of focusing on general care and prevention services. Among the true causes of the lack of coverage of basic care: the repetitive breaks in the stock of drugs, the virtual absence of preventive maintenance of medical equipment, the unavailability of some basic health care services, the lack of respect permanence, etc.

There has been a lack of coordination between the four levels of care provision, and between public and private health facilities. The result is that the patient traces his path to care between different levels of care in relation to his financial capabilities.

The gravity model can be applied to the case of Algerian community care through the following reasons:

- The distance (geographic variable) significantly influences the decision of the health care recipient, and especially the choice of care structure;

- We recorded wilayas that attract more demand for primary care than others, especially the two wilayas (Constantine and Batna) which have UHC;

- We noted inequalities in recourse within the same wilaya, because of objective and other subjective reasons.

\section{CONCLUSION}

There is currently a global trend to emphasize nearby care, and therefore to put "primary care" at the center of the health care system. Proximity is a component of accessibility, but not the only one. Indeed, the difficulties of access are not only physical (geographical aspect), but also cultural or financial (mode of care).

There is no general rule about the conditions that affect the decision to seek care. With regard to empirical studies carried out in an Anglo-Saxon country, the only certainty concerns a low demand for care for the people who are furthest away. In terms of prevention, the effect of accessibility seems more marked than for curative care. Still, the physical distance is one component among others that influences the decision to seek care.

After the development of the 1980 health map, the health sector became the cornerstone of primary care distribution, and since Executive Decree 07/140, the NHPF took over the distribution of primary health care (JORADP, 2007). The main objective of this restructuring was to provide good coverage of this kind of care through the decentralization of these basic hospital structures, which for a long time were the focus of decisions made for basic health care structures. Nevertheless, Executive Order 07/140 has removed these structures from their primary purpose, 
which is prevention in the broad sense, since it has provided them with medicaltechnical services that provide more than preventive care.

Low financial endowments and a glaring lack of medical and paramedical human resources have stymied the role of these NHPF, and have favored the requester's recourse to hospital emergencies. In return, the number of these structures is sufficient, and their proximity to living environments, despite the derisory number of services rendered, have been able to meet certain needs of the inhabitants.

\section{REFERENCES}

Aissaoui, N. (2014). La responsabilité de la qualité des soins à contrecarrer l'hospitalisation évitable: Etude de cas d'un échantillon de polycliniques en Algérie, art. in revue des recherches économiques et financières de la faculté SESCSG de l'université d'Oum El Bouaghi. 1: 105-124.

Aissaoui, N. (2017). La gestion des structures de soins de proximité en Algérie entre équité et efficience - Cas des EPSP dans la région sanitaire Est, numéro 01 janvier 2017, revue EWASH\&TI, Université El Hoceima, Maroc. 1: 27-36.

Aissaoui, N. (2017). Les impacts des déterminants sociaux de la santé sur la santé publique : Cas de la région sanitaire Est de l'Algérie, numéro 11, Vol.1 mars 2017, Annales de sciences de la santé, Université de Oujda, Maroc. 10:10-25.

Aissaoui, N \& Brahamia, B. (2014). Vers une dynamisation des structures de soins de santé de base en Algérie, revue des sciences humaines de l'université Constantine1. 40, 65-79.

Bentham, $G$ et al. (1995). Factor affecting non-response to cervical cytology screening in Norfolk, Social Science and Medicine, England, vol n ${ }^{\circ} 40$, pp 131135 .

Frenk, F. (1985). The concept and measurement of accessibility, Salud Publica de Mexico, p 438.

Gabrielli, V.L et al. (2001). Les soins de proximité : une exception française, CREDES, Paris, pp 17-18.

http://www.desktop.arcgis.com/fr/desktop/.../how-original-huff-model-works.htm/ Accessed in 15/01/2016.

http://www.grasland.script.univ-paris-diderot.fr/go303/ch5/doc_ch5.htm/ Accessed in $15 / 01 / 2016$.

http://www.parisgeo.cnrs.fr/cg/spesp/wp1/index.htm/ Accessed in 20/02/2016.

Hubert, E. (2010). Médecine et soins de proximité, document pdf, Accessed in 28juillet 2010, p 6.

JORADP, Décret exécutif nº 07-140 du 2 Joumada El Oula 1428 correspondant au 19 mai 2007 portant création, organisation et fonctionnement des établissements publics hospitaliers et des établissements publics de santé de proximité, Art. 6

Noin, D. (1988). Géographie de la Population, Masson, Paris, pp. 273-274

Ravenstein, E. (1985). The Laws of Migration, Journal of the Statistical Society of London, vol. 48, $\mathrm{n}^{\circ}$ 2. p. 167-235, and Second Paper, vol. 52, $\mathrm{n}^{\circ}$ 2, p. 241-305, 1889. 